\title{
miRNA and mRNA studies reveal pollination activates hormonal signaling and increases fruit set in the apomictic tree Zanthoxylum bungeanum Maxim
}

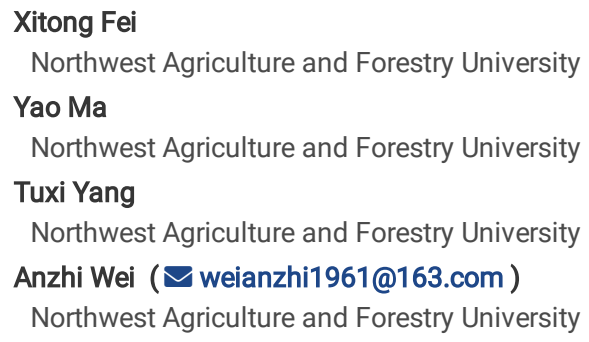

Research article

Keywords: Zanthoxylum bungeanum Maxim., Apomixis, Hormones, miRNA-mRNA, fruit set, apomictic tree

Posted Date: September 16th, 2019

DOI: https://doi.org/10.21203/rs.2.14447/v1

License: (9) (1) This work is licensed under a Creative Commons Attribution 4.0 International License. Read Full License 


\section{Abstract}

Background Apomixis is a form of reproduction that does not involve fertilization of female by male gametes but instead produces offspring from the female parent directly. The progeny of apomixis is genotypically identical to the female parent and so maintains any elite traits of the female parent. Apomixis has considerable potential in genetic plant breeding. However, the mechanism of apomictic reproduction remains unclear. Zanthoxylum bungeanum is an apomictic plant. Studies on miRNAs, mRNAs, hormone changes and fertilization process of the pollinated and non-pollinated materials of Zanthoxylum bungeanum allows screening of the important regulatory factors of the apomictic process at both physiological and molecular levels. This information should be of considerable help in understanding the mechanism of apomixis in this species.

Results Our results show that Zanthoxylum bungeanum pollen can germinate on the stigma, and that the pollen tube can extend to the ovary wall after two days but that it then degenerates about the fifth day and before reaching the egg cell. So fertilization does not occur. Nevertheless, pollination did increase fruit set from $74.12 \%$ (unpollinated) to $89.31 \%$ (pollinated). The reproductive mode of the Zanthoxylum bungeanum cultivar 'Hancheng Dahongpao' was identified as obligate apomixis. Enrichment analysis of differential genes indicates that pollination activates genes involved in the synthesis of ABA, IAA, GA3 and JA, and that genes related to asexual development, genes involved in flower development, and transcription factors are also activated. RT-qPCR verification shows that the relative expression levels of mRNAs and miRNAs related to hormone signaling pathways and flower development were negatively correlated. Also, that miRNA is an important factor influencing hormone regulation after pollination of this apomictic species. The contents of ABA, IAA, GA3 and JA were all significantly increased following pollination.

Conclusions In general, although pollination does not result in fertilization in this species, it does activate mRNAs and miRNAs which serve as signals to activate the anabolic pathways for ABA, IAA, GA3 and JA. Increased levels of these hormones result in increased fruit set.

\section{Background}

Zanthoxylum bungeanum Maxim. $(Z B)$, common name Chinese prickly ash, is a shrub or dungarunga belonging to the rutaceae. There are about 250 species of the genus Zanthoxylum, which is widely distributed round the world, though most species of this genus originate in Asia [1]. Based on the color of the fruit at maturity, it is divided into two types: red Chinese prickly ash and green Chinese prickly ash. The young leaves of $Z B$ can be eaten as a vegetable and the fruits, stems and roots can be used as medicines [2]. The fruit skin is one of China's eight most important condiments. Having a unique numbing taste. This product is in wide use in Asian cuisine and is an important seasoning for the traditional Chinese hot pot $[3,4]$. The fruit skin of $Z B$ is a traditional herbal medicine in China and has been in use for more than 2,000 years [5]. Over 140 chemical compounds have been identified in $Z B$, including alkaloids, anthraquinones, flavonoids and free fatty acids [6-9]. Used as a medicine, the skin has anti-inflammatory, antibacterial and insecticidal effects [10-13]. For these reasons, $Z B$ is an important species, that also has significant potential for commercial development.

Interestingly, the normal reproductive mode of $Z B$ is apomictic [14] - a mode that produces viable seed without pollination. Hence, the genotype of the offspring is identical to that of the female parent $[15,16]$. In a commercial species, apomixis can be both a disadvantage and an advantage. The apomictic mechanism maintains the superior traits of the female for breeding, and can also provide a useful model for the genetic breeding of plant traits. However, the performance of apomictic plants following pollination has rarely been reported. Therefore, a study of differences between plants resulting from pollination and from non-pollination should help reveal the mechanisms of apomixis and thus provide a useful reference for plant genetic breeding research.

\section{Results}

\section{Pollen germination}

Pollen germination tests were carried out on pollen on the in vitro germination medium, and pollen germination rate was counted and expressed as a percentage. The results showed the pollen germination rate of $Z B$ pollen increased from $4.30 \%$ after $3 \mathrm{~h}$ to $10.70 \%$ after $12 \mathrm{~h}$ (Figure 1 and Table 1). In general, the germination rate of $Z B$ pollen is low, which presents a huge obstacle to sexual reproduction in this species.

Figure 1. In vitro germination and pollen morphology of Zanthoxylum bungeanum pollen. (a) Pollen germination In vitro for 3 h, (b) Pollen germination In vitro for 6 h, (c) Pollen germination In vitro for 12 h, (d) anther, (e) Pollen grain, (f) Pollen grain.

Table 1. Germination rate of Zanthoxylum pollen in vitro. 


\begin{tabular}{|l|l|l|l|}
\hline Time (h) & 3 & 6 & 12 \\
\hline Germination rate (\%) & $4.30 \pm 0.30$ & $6.20 \pm 0.50$ & $10.70 \pm 1.40$ \\
\hline
\end{tabular}

Figure 2. Germination of pollen on the stigma of Zanthoxylum bungeanum. ca: callosum, ce:cellulose, ow: ovary wall,po:pollen, pt:pollen tube, sdp: stigma drop position.

Fluorescence microscopy shows pollen germinates on the stigma of $Z B$. Pollen tube growth commenced by $6 \mathrm{~h}$ (Figure 2 ). After $12 \mathrm{~h}$ pollen tube began to extend. After $2 \mathrm{~d}$, the pollen tube penetrated the ovary wall. By $3 \mathrm{~d}$ after pollination the stigma begins to wither. Stigma fluorescence gradually dims during the withering process. After $4 \mathrm{~d}$, the stigma falls off but the pollen tube in the ovary wall can still extend further downwards. After $5 \mathrm{~d}$, the pollen tube is broken down into callosum so the fertilization process cannot be completed. We observed 300 samples and found no successful fertilization in any of them. It is thus preliminarily concluded that the reproductive mode of $Z B$ cv. 'Hancheng Dahongpao' is obligate apomixis.

\section{Path enrichment analysis}

The pathway enrichment analysis of differential genes reveals changes before and after pollination. It can be seen from Figure 3 that pollination has a significant effect on the various pathways of $Z B$ than unpollinated. After pollination, hormone signal transduction is most active, as are metabolic pathways including starch and sucrose metabolism, glycolysis/gluconeogenesis and phenylpropanoid synthesis. Figure 3b shows the pathway of increased expression after pollination, and Figure 3c shows the pathway of decreased expression after pollination. More than 100 genes were enriched and show elevated expression levels after pollination in the hormone signal transduction pathway. Meanwhile, starch and sucrose metabolism, glycolysis/gluconeogenesis, amino sugar and nucleotide metabolism all showed significant downward trends.

Figure 3. Path enrichment analysis. (a) Total pathway enrichment analysis. (b) Active pathway after pollination. (c) Inactive pathway after pollination.

Figure 4. Differential gene Venn diagram and volcano map.

Transcriptome sequencing of pollinated and unpollinated fruits showed that a total of 69,131 reads were detected. Of these 4,431 were unique to unpollinated material and 4,078 were unique to pollination material (Figure 4). As indicated in the volcano map 7,102 genes were up-regulated and 6491 genes were down-regulated. From this it can be inferred that pollination has a strong influence on transcriptome level in $Z B$ fruits.

miRNAs and target genes expression patterns

By analyzing interactions between miRNAs and mRNA in pollinated and non-pollinated fruit, it was found that pollinated fruits were more active in a range of hormone signaling pathways. Pollination can activate ABA, IAA, GA3, jasmonic acid synthesis genes and genes associated with asexual development, such as somatic embryogenesis receptor kinase 2 (SERK2), agamous-like MADS-box protein (AGL9), also activating a large number of flower development genes and transcription factors. To further determine the relationship of miRNAs to target genes, RT-qPCR was used to detect relative expression levels of miRNAs and their target genes. 
According to the results of the RT-qPCR, the reliability of transcriptome and miRNA sequencing results can be determined and the relative expression levels of some miRNAs and their target genes after pollination were confirmed (Figure 5). The results show the expression levels of the ABA, IAA, GA3 and JA synthesis genes and some transcription factors and their corresponding miRNAs were negatively correlated after pollination. This indicates miRNAs and mRNAs are widely involved in the regulation of hormones after pollination of this apomictic Chinese prickly ash cultivar.

Figure 5. Relative expression levels of miRNAs and their target genes.

\section{Hormone content analysis}

The transcriptome and miRNA sequencing shows many hormone pathways became active after pollination. We recorded the levels of four hormones ABA, IAA, GA3 and JA were for pollinated and unpollinated materials. The results show the four hormones were significantly higher in the pollination material than in the unpollinated (Figure 6). This indicates pollination can activate the synthetic pathway of these four hormones, it also suggests these four hormones participate in the development of embryos and fruits of $Z B$ and, ultimately, in fruit set.

Figure 6. Hormone content of unpollinated and pollinated material of Zanthoxylum bungeanum.

Comparing the pollinated with the unpollinated $Z B$ material (Table 2), it is clear that pollination significantly increased fruit set rate but had little effect on fruit size.

Table 2. Pollination and non-pollination fruit set rate and fruit size.

\begin{tabular}{|l|l|l|}
\hline Samples & Non-pollination & Pollination \\
\hline Fruit set rate & $74.12 \% \mathrm{~b}$ & $89.31 \% \mathrm{a}$ \\
\hline Fruit length (axial) & $5.83 \pm 0.72 \mathrm{a}$ & $5.85 \pm 0.56 \mathrm{a}$ \\
\hline Fruit diameter (transverse) & $5.59 \pm 0.81 \mathrm{a}$ & $5.60 \pm 0.88 \mathrm{a}$ \\
\hline
\end{tabular}

\section{Conclusion}

Pollen of $Z B$ was cultured in vitro on a solid culture medium for $12 \mathrm{~h}$. At this stage germination percentage was only $10.77 \%$.

Fluorescence microscopy showed that the pollen does germinate on the $Z B$ stigma and that the pollen tube extended to the ovary after $2 \mathrm{~d}$ but then degenerated to callosum after $5 \mathrm{~d}$ without fertilization. The reproductive mode of $Z B$ (Hancheng Dahongpao) is identified as obligate apomixis. Enrichment analysis of differentially expressed genes in the pollination and non-pollination materials indicate plant hormone signaling pathways were activated by fertilization. The relative expressions of ABA, IAA, GA3 and JA were up-regulated. At the same time, genes related to asexual development were also activated, including somatic embryogenesis receptor kinase 2 (SERK2) and agamous-like MADS-box protein (AGL9). A large number of other genes and transcription factors related to flower development were also activated. RT-qPCR showed the relative expression levels of mRNAs and miRNAs related to the hormone signaling pathway and to flower development were negatively correlated, suggesting miRNA is an important factor influencing hormone regulation after 
pollination of apomictic $Z B$. Comparison of pollination and non-pollination materials showed increases in the contents of ABA, IAA, GA3 and JA. Nevertheless, although pollination did not result in fertilization, it did increase fruit set significantly.

\section{Discussion}

Double fertilization is one of the most common reproductive modes in plants, egg cells combine with the polar nuclei of pollen [23]. The fertilized egg cells then develop into embryos. The latter develops into endosperm, which provides energy for seed germination.

Nevertheless, some plants can form viable seeds without fertilization having taken place. This indicates fertilization is not essential for seed formation [24]. Analysis of hormones in unpollinated and pollinated ovaries of various species reveals that fertilized eggs and developing seeds release hormones that are important determinants of fruit set $[25,26]$.

There are many obstacles to the success of sexual reproduction in plants. In this study, the in vitro germination rate of pollen was very low, with a germination rate after $12 \mathrm{~h}$ of only about $11 \%$. In addition, pollen research in the Zanthoxylum piperitum showed that the pollen germination rate was only $10 \%$, which was mutually verified with the results of this study. This is far lower than for other species [27-30]. Our results for pollen germination in vivo indicate the pollen tube has difficulty extending into the ovary to reach the egg cells with eventual degeneration of the pollen tube prior to reaching the egg cells, so preventing fertilization. Nevertheless, pollination did increase the levels of ABA, IAA, GA3 and JA and fruit set.

Figure 7. Hormone signal regulation model after pollination of Zanthoxylum bungeanum.

In most plants, pollination is followed by fertilization, the formation of a zygote and this the development of a fruit containing viable seed(s). In an obligate apomictic plant, fertilization fails but the fruit nevertheless develops and is contains viable seeds. By analyzing the pollination process in $Z B$, we show that pollination fails to combine the male and female gametes but it does increase the production of ABA, IAA, GA3 and JA and so the fruit sets. We speculate that in $Z B$, pollination fails to achieve fertilization but nevertheless delivers a signal which activates a series of hormone synthesis pathways, which produce hormones that promote both fruit set and fruit development (Figure 7).

This view is supported in tomato where it has been found that low levels of ABA lead to poor fruit development [31]. In cherry, ABA and its signal transduction related gene PaSnRK2.1/2.2/2.4 are highly expressed in the ovary and young fruit. This indicates ABA plays an important role in fruit development [32]. In Arabidopsis, ABA has also been shown to act as a switch for flower development. It has been shown that ABA activates photoperiod response genes and flowering genes to promote flowering, but ABA can also inhibit flowering, independent of the flowering gene [33]. The interaction between hormones is an important element of floral organ development. In the citrus ovule, it has been shown that IAA activates the expression of the GA3 biosynthetic gene, while also reducing the breakdown of GA3. Applications of exogenous IAA or GA3 to unpollinated citrus flowers restores fruit set and fruit development to the same levels as pollination [34]. ABI5 is a transcription factor that binds specifically to the auxin response element 5'-TGTCTC-3', thereby functioning as a transcriptional activator. It can form a dimer with Aux/IAA protein to participate in the expression of auxin while promoting the synthesis of JA [35-37]. ARF7 is also an auxin response factor with high expression levels in tomato ovaries and these regulate fruit development [38]. In many plants, successful pollination and fertilization can induce increases in auxin and gibberellin levels in the ovary [39-41]. Moreover, after pollination, auxin and gibberellin response genes were up-regulated, indicating auxin and gibberellin signals can be induced by pollination [42].

We selected 300 samples to identify the reproductive mode in $Z B$ Hancheng Dahongpao. We found no evidence of successful fertilization. We conclude its reproductive mode is obligate apomictic. However, due to the complex genetic background of $Z B$ genotypes and the wide phenotypic variability among its cultivars $[43,44]$, we cannot exclude the possibility that some $Z B$ genotypes may well be 
able to reproduce through normal sexual processes. We recorded fruit set and fruit size of pollinated and unpollinated flowers. These indicate that pollination had no significant effect on the development of fruit size in $Z B$ but can significantly increase fruit set.

Commercial cultivars of $Z B$ are generally considered dioecious, and yet there are usually no male plants in a plantation. Therefore, we suggest a small proportion of male plants should be co-established in a commercial $Z B$ plantation to increase fruit set, and thus fruit yield.

\section{Methods}

Fruit of the $Z B$ cultivar 'Hancheng Dahongpao' was collected from the Fengxian Experimental Station of the Northwest A\&F University

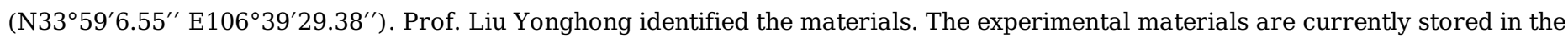
specimen room of the College of Forestry, Northwest A\&F University (WUK 0028639). A healthy five-year-old tree with uniform growth was selected and the unopened flowers were continuously sampled at $1 \mathrm{~d}$ intervals. A portion of the sample was stored in liquid nitrogen in a $-80^{\circ} \mathrm{C}$ refrigerator, and another portion placed in FAA fixative. Each analysis was repeated three times.

\section{Pollen germination}

The collected $Z B$ anthers were surface sterilized with $1 \%$ sodium hypochlorite for 8 minutes, washed three times with sterile water, and then the pollen in the anthers was transferred to a solid medium. The medium components were agarose (5.8 $\mathrm{g} / \mathrm{L}$ ), sucrose (50 $\mathrm{g} / \mathrm{L})$ and boric acid $(0.01 \mathrm{~g} / \mathrm{L})$ [17-19]. It was then incubated at $25 \pm 2{ }^{\circ} \mathrm{C}$ with a light intensity of 2000 lx. Pollen tube growth greater than one cell diameter. Pollen germination was assessed after 3, 6 and $12 \mathrm{~h}$.

\section{Total RNA extraction and reverse transcription}

RNA samples were extracted using the TaKaRa MiniBEST Plant RNA Extraction Kit (TaKaRa, Beijing, China). The Mir-X miRNA FirstStrand Synthesis Kit (TaKaRa, Beijing, China) was used for reverse transcription of mRNAs and the Mir-X ${ }^{\mathrm{TM}}$ miRNA First Strand Synthesis Kit (TaKaRa, Beijing, China) was used for reverse transcription of miRNAs.

\section{RT-qPCR}

The RT-qPCR reaction was carried out using the cDNA of the collected material as a template. The primers for RT-qPCR were designed by Primer Premier 5.0 (Palo Alto, CA, USA). These primers are listed in Table 3. The RT-qPCR reaction was carried out in a CFX96 RealTime PCR Detection System with a reaction system (Bio-Rad, Hercules, CA, USA) of $10 \mu L$ containing $5 \mu$ L of $2 \times$ SYBR Premix Ex Taq II (TaKaRa), $0.5 \mu \mathrm{L}$ of upstream and downstream primers, $3 \mu \mathrm{L}$ of $\mathrm{ddH}_{2} \mathrm{O}$, and $1 \mu \mathrm{L}$ of cDNA as template. The reaction procedure was at $95^{\circ} \mathrm{C}$ for $30 \mathrm{~s}$, then 35 cycles at $94^{\circ} \mathrm{C}$ for $5 \mathrm{~s}$, at $54^{\circ} \mathrm{C}$ for $30 \mathrm{~s}$ and at $72^{\circ} \mathrm{C}$ for $45 \mathrm{~s} . Z B U B Q$ and $Z B U B A$ were used as reference genes to correct the relative expression levels of mRNAs [20] and U6 was used as a reference gene for miRNAs [21].

Table 3. RT-qPCR primers. 


\begin{tabular}{|c|c|c|c|c|c|}
\hline $\begin{array}{l}\text { Gene } \\
\text { Name }\end{array}$ & Description & upstream Primer Sequence $(5-3)$ & $\begin{array}{l}\text { downstream Primer Sequence (5 } \\
-3 \text { ) }\end{array}$ & miRNAs & Primer Sequence $(5-3)$ \\
\hline$A G L 9$ & $\begin{array}{l}\text { Agamous-like } \\
\text { MADS-box } \\
\text { protein AGL9 } \\
\text { homolog }\end{array}$ & CTGATGAGCGAAGCAAATAAG & GTCCAAGGGTTGAAAAAAGGT & $\begin{array}{l}\text { ath- } \\
\text { miR156b- } \\
3 p\end{array}$ & TGCTCACCTCTCTTTCTGTC \\
\hline$I A A 8$ & $\begin{array}{l}\text { Auxin- } \\
\text { responsive } \\
\text { protein IAA8 }\end{array}$ & GGAAAACACACTGGCCACTAAT & TCCATGCTGACCTTGACAAACA & $\begin{array}{l}\text { ath- } \\
\text { miR165a- } \\
3 p\end{array}$ & TCGGACCAGGCTTCATCCC \\
\hline M3KE1 & $\begin{array}{l}\text { MAP3K epsilon } \\
\text { protein kinase } \\
1\end{array}$ & CTTAGAGAATCTTCAGCGGGCA & CCATATCACACAGTAGAGGCAA & $\begin{array}{l}\text { ath- } \\
\text { miR166a- } \\
3 p\end{array}$ & TCGGACCAGGCTTCATTCC \\
\hline$A B F 4$ & $\begin{array}{l}\text { ABSCISIC } \\
\text { ACID- } \\
\text { INSENSITIVE } \\
\text { 5-like protein } 7\end{array}$ & AGGATCTTTAACTTTGCCACG & CACTCACATCTTCAGCACCAG & $\begin{array}{l}\text { ath- } \\
\text { miR167d }\end{array}$ & TGAAGCTGCCAGCATGATC \\
\hline MYB44 & $\begin{array}{l}\text { Transcription } \\
\text { factor MYB44 }\end{array}$ & ACAACAACTCAATCCACTCGGT & TCСТTATCATCTCTTGCATCAC & $\begin{array}{l}\text { ath- } \\
\text { miR396a- } \\
3 p\end{array}$ & GTTCAATAAAGCTGTGGGA \\
\hline G2OX8 & $\begin{array}{l}\text { Gibberellin } 2 \text { - } \\
\text { beta- } \\
\text { dioxygenase } 8\end{array}$ & TTGATAAGAAGAGCCAAGAAGAC & TTAGTGAAACCAGCAACAGAAGT & $\begin{array}{l}\text { ath- } \\
\text { miR5658 }\end{array}$ & ATGATGATGATGATGATGA \\
\hline$A R F 6$ & $\begin{array}{l}\text { Auxin response } \\
\text { factor } 6\end{array}$ & TTCTATTTCATTGСССССТTTT & TTGTGGAATCACTATTGCTCCC & novel_10 & AGATCATGTTGCAGTTTCA' \\
\hline$A S Y 3$ & $\begin{array}{l}\text { Meiosis-specific } \\
\text { protein ASY3 }\end{array}$ & CAGAAAATAAAGGTGAGGGTGC & AATGGGTGCTGTTTGGTAAAAG & novel_27 & AACGAGTCTGATGGTTCAA \\
\hline$A R F 2$ & $\begin{array}{l}\text { Auxin response } \\
\text { factor } 2\end{array}$ & ATGGTTGGTGTGAGTGGAGAAGGGG & ССССТТСТССАСТСАСАССААССАТ & novel_29 & AGCTCTCTGAACTCCAAGT \\
\hline$F L K$ & $\begin{array}{l}\text { Flowering locus } \\
\text { K homology } \\
\text { domain }\end{array}$ & TCAAATACCCAGTCGGCACCAT & CTGTCATCTCCCCAGGAACACC & novel_38 & TGCTTACTTCTCTTTCTGTC \\
\hline WRKY4O & $\begin{array}{l}\text { Probable WRKY } \\
\text { transcription } \\
\text { factor } 40\end{array}$ & АTCCTTCTCCTCGAGCCTACTT & TTGGTCCTCAACACTTCTTTGT & novel_48 & CAACAGAATCGGCCTTCTT \\
\hline$A R F 2$ & $\begin{array}{l}\text { Auxin response } \\
\text { factor } 2\end{array}$ & AGCAGAGGTTTACTGGGACC & ACATCGGAAGTGGATTGAGA & novel_56 & TCGGACTTTCGCTATCTTT] \\
\hline SERK2 & $\begin{array}{l}\text { Somatic } \\
\text { embryogenesis } \\
\text { receptor kinase } \\
2\end{array}$ & GAAGATAAAGGTTTGGGCTT & GTACAGGGATTGACGAGGGT & novel_64 & ATCGTCCGCATATGCAATA \\
\hline PIE1 & $\begin{array}{l}\text { Protein } \\
\text { PHOTOPERIOD- } \\
\text { INDEPENDENT }\end{array}$ & ACTCGGGATTTGATAATGGACCT & TCTTCCTCAATAGTGTGCTCGTC & novel_66 & TTTGGACTGAAGGGAGCTC \\
\hline
\end{tabular}




\begin{tabular}{|c|c|c|c|c|c|}
\hline & $\begin{array}{l}\text { EARLY } \\
\text { FLOWERING } 1\end{array}$ & & & & \\
\hline PSF2 & $\begin{array}{l}\text { DNA replication } \\
\text { complex GINS } \\
\text { protein PSF2 }\end{array}$ & CAAGAAGTAACTAGACAGCGGCA & GAAAAGAGAGAGGAAAGAAACGG & novel_76 & TTCTCTTTTACAAGATTGTA \\
\hline$F B P 1$ & $\begin{array}{l}\text { Floral homeotic } \\
\text { protein FBP1 }\end{array}$ & AATTCTTCAGTTTGCTTCCTTG & AGATGTGACATCATTTCCСTTG & novel_77 & AAAGGCCGAACCTCACCTG \\
\hline U6 & $\begin{array}{l}\text { Reference gene } \\
\text { of miRNAs }\end{array}$ & TTGGACCATTTCTCGATTTGTGC & CCTTAGGGGACATCCGATAAAATTG & - & - \\
\hline$Z B U B Q$ & $\begin{array}{l}\text { ubiquitin } \\
\text { extension } \\
\text { protein }\end{array}$ & TCGAAGATGGCCGTACATTG & TCCTCTAAGCCTCAGCACCA & - & - \\
\hline$Z B U B A$ & $\begin{array}{l}\text { ubiquitin-60S } \\
\text { ribosomal } \\
\text { protein L40 }\end{array}$ & GACTTAGGGGAGGGATTATTGAG & TTCTTCTTCCGACAGTTTACAGC & - & - \\
\hline
\end{tabular}

\section{Hormone content determination}

Based on the endogenous hormone extraction and determination methods of Niu Huiling et al. [22] we took a $0.5 \mathrm{~g}$ tissue sample, extracted it with $80 \%$ methanol, purified it, dry it under a stream of nitrogen, diluted it to 1.0 mL. We then determined the auxin (IAA), gibberellin $\left(\mathrm{GA}_{3}\right)$, JA (jasmonic acid) and abscisic acid (ABA) contents of $Z B$ fruits at different times by LC-MS/MS. ). There were two samples (pollinated and non-pollinated fruit) and each was repeated three times. Details of the LC-MS/MS were liquid chromatograph (Shimadzu; Wondasil C18 column $(150 \mathrm{~mm} \times 4.6 \mathrm{~mm}, 5 \mu \mathrm{m})$; column temperature $35^{\circ} \mathrm{C}$; injection volume $2 \mu \mathrm{L}$; flow rate $0.5 \mathrm{~mL} \cdot \mathrm{min}-1$; mobile phase A: ultrapure water; Phase B: methanol; gradient elution procedure: $0 \sim 6.5$ min, $40 \%$ B; $6.5 \sim 11.0$ min, $100 \%$ B; $11.0 \sim$ $15.0 \mathrm{~min}, 40 \% \mathrm{~B}$ ) and mass spectrometer (API 2000; mass spectrometry. Conditions: API; ion source temperature: $450^{\circ} \mathrm{C}$; scanning method: multiple reaction monitoring MRM).

\section{miRNA target gene prediction}

The psRNATarget online site (http://plantgrn.noble.org/psRNATarget/) was used for interaction analysis between miRNA and target mRNA. The miRNAs and mRNA sequences were uploaded to the website and the conditions were set to the default values. The interaction relationship between miRNAs and mRNA was analyzed, and the most reliable results were obtained by screening.

\section{Abbreviations}


ABA: Abscisic acid; AGL9: agamous-like MADS-box protein; GA: Gibberellin acid; IAA: Indole-3-acetic acid; JA: jasmonic acid; SERK2: somatic embryogenesis receptor kinase 2.

\section{Declarations}

\section{Acknowledgements}

Thanks to the experimental technical support provided by Dr. Huang Dong.

\section{Authors' contributions}

A.W. conceived the project. X.F. designed the experiments and performed the experiment. X.F. wrote the paper. All authors (X.F., Y.M., T.Y. and A.W.) discussed the results and commented on the manuscript.

\section{Funding}

The funders had no role in the experiment design, data analysis, decision to publish or preparation of the manuscript. This study was financially supported by the National Key Research and Development Program Project Funding (2018YFD1000605).

\section{Availability of data and materials}

Not applicable.

\section{Ethics approval and consent to participate}

Not applicable.

\section{Consent for publication}

Not applicable.

\section{Competing interests}

The authors declare that they have no competing interests.

\section{Declarations}

The authors declare there are no commercial financial conflicts of interest.

\section{References}

1. Xiao-Qin, Y.U., et al., Evaluation of Specific Quality of Zanthoxylum bungeanum Maxim and Zanthoxylum schinifolium Sieb. et Zucc. Food Science, 2009. 30(15): p. 45-48.

2. Bhatt, V., et al., Simultaneous quantification and identification of flavonoids, lignans, coumarin and amides in leaves of Zanthoxylum armatum using UPLC-DAD-ESI-QTOF-MS/MS $\square$. Journal of Pharmaceutical \& Biomedical Analysis, 2017. 132: p. $46-55$.

3. Li, J.H., S.H. Zhang, and L.H. Kong, Research development of Chinese prickly ash. China Condiment, 2009.

4. Fei, X., et al., Patterns of Drought Response of 38 WRKY Transcription Factors of Zanthoxylum bungeanum Maxim. Int J Mol Sci, 2018. 20(1).

5. Li, X., et al., The Chemical and Genetic Characteristics of Szechuan Pepper (Zanthoxylum bungeanumandZ. armatum) Cultivars and Their Suitable Habitat. Frontiers in Plant Science, 2016. 7.

6. Xiong, Q., et al., Alkylamides from pericarps of Zanthoxylum bungeanum. Phytochemistry, 1997. 46(46): p. 1123-1126.

7. Xiaogen, Y., Aroma constituents and alkylamides of red and green huajiao (Zanthoxylum bungeanum and Zanthoxylum schinifolium). Journal of Agricultural \& Food Chemistry, 2008. 56(5): p. 1689-96.

8. Yang, L.C., et al., Polyphenolics Composition of the Leaves of Zanthoxylum bungeanum Maxim. Grown in Hebei, China, and Their Radical Scavenging Activities. J Agric Food Chem, 2013. 61(8): p. 1772-1778.

9. Xia, L., et al., Compositional and Antioxidant Activity Analysis of Zanthoxylum bungeanum Seed Oil Obtained by Supercritical CO2 Fluid Extraction. Journal of the American Oil Chemists' Society, 2010. 88(1): p. 23-32.

10. Mi, X., et al., Study on the extraction, separation and antimicrobial effect of volatile oil from Zanthoxylum bungeanum maxim. Journal of Nanjing Normal University, 2004. 27(4): p. 63-66. 
11. Zhang, Z., et al., Zanthoxylum bungeanum pericarp extract prevents dextran sulfate sodium-induced experimental colitis in mice via the regulation of TLR4 and TLR4-related signaling pathways. International Immunopharmacology, 2016. 41: p. 127-135.

12. Bowers, W.S., et al., Insect Repellents from the Chinese Prickly Ash Zanthoxylum bungeanum. Journal of Natural Products, 1993. 56(6): p. 935-938.

13. Singh, G., et al., Anthelmintic efficacy of aqueous extract of Zanthoxylum armatum DC. seeds against Haemonchus contortus of small ruminants. Journal of Parasitic Diseases, 2016. 40(2): p. 528-532.

14. Liu, Y., Apomixis in Zanthoxylum bungeanum and Z. simulans. Journal of Genetics \& Genomics, 1987. 14(2): p. 107-113.

15. Bicknell, R.A. and A.M. Koltunow, Understanding apomixis: recent advances and remaining conundrums. Plant Cell, 2004.16 Suppl: p. S228-45.

16. Matzk., F., et al., Reconstruction of reproductive diversity in Hypericum perforatum L. opens novel strategies to manage apomixis. Plant Journal, 2001. 26(3): p. 275-282.

17. Ji-wen., H., et al., Research on Pollen Germination and Vigor of Toona sinensis. Forest $\square$ esearch, 2019. 32(2): p. $160-165$.

18. Shivanna, K.R., H.F. Linskens, and M. Cresti, Pollen viability and pollen vigor. Theoretical \& Applied Genetics, 1991. 81(1): p. 38-42.

19. Hong-Zao, H.E., Study on the Pollen Viability of Zanthoxylum planispinum var.dingtanensis and its Response to Zinc. Journal of Anhui Agricultural Sciences, 2007.

20. Fei, X., et al., Expression Stabilities of Ten Candidate Reference Genes for RT-qPCR in Zanthoxylum bungeanum Maxim. Molecules, 2018. 23(4).

21. Zhang, X., et al., miRNA and $m R N A$ expression profiles reveal insight into the chitosan-mediated regulation of plant growth. J Agric Food Chem, 2018. 66(15): p. 3810-3822.

22. Hui-ling., N., et al., Flower Formation and Endogenous Hormones Dynamic in Chinese Jujube. Acta Horticulturae Sinica, 2015. 42(4): p. 655-664.

23. Berger, F., et al., Double fertilization - caught in the act. Trends in Plant Science, 2008. 13(8): p. $437-443$.

24. Gillaspy, G., H. Bendavid, and W. Gruissem, Fruits: A Developmental Perspective. Plant Cell, 1993. 5(10): p. 1439-1451.

25. Koltunow, A.M., Special Review Issue on Plant Reproduction // Apomixis: Embryo Sacs and Embryos Formed without Meiosis or Fertilization in Ovules. Plant Cell, 1993. 5(10): p. 1425-1437.

26. Koltunow, A.M., R.A. Bicknell, and A.M. Chaudhury, Apomixis: Molecular Strategies for the Generation of Genetically Identical Seeds without Fertilization. Plant Physiology, 1995. 108(4): p. 1345-1352.

27. Sato, S., et al., Establishment of reliable methods of in vitro pollen germination and pollen preservation of Brassica rapa (syn. B. campestris). Euphytica, 1998. 103(1): p. 29-33.

28. Fan, L.M., et al., In vitro Arabidopsis pollen germination and characterization of the inward potassium currents in Arabidopsis pollen grain protoplasts. Journal of Experimental Botany, 2001. 52(361): p. 1603-1614.

29. ROSELL, HERRERO, and G. V., Pollen germination of cherimoya (Annona cherimola Mill.). In vivo characterization and optimization of in vitro germination. Scientia Horticulturae, 1999. 81(3): p. 251-265.

30. Ylstra, B., et al., Steroid Hormones Stimulate Germination and Tube Growth of in Vitro Matured Tobacco Pollen. Plant Physiology, 1995. 107(2): p. 639-643.

31. Nitsch, L., et al., ABA-deficiency results in reduced plant and fruit size in tomato. Journal of Plant Physiology, 2012. 169(9): p. 878883.

32. Leng, P., et al., Expression pattern of ABA metabolic and signalling genes during floral development and fruit set in sweet cherry. Plant Growth Regulation, 2017. 84(4): p. 1-10.

33. Riboni, M., et al., ABA-dependent control of GIGANTEA signalling enables drought escape via up-regulation of FLOWERING LOCUS T in Arabidopsis thaliana. Journal of Experimental Botany, 2016. 67(22): p. 6309-6322.

34. Bermejo, A., et al., Auxin and Gibberellin Interact in Citrus Fruit Set. Journal of Plant Growth Regulation, 2017. 37(2): p. 491-501.

35. Wu, J., et al., Gladiolus hybridus ABSCISIC ACID INSENSITIVE 5 (GhABI5) is an important transcription factor in ABA signaling that can enhance Gladiolus corm dormancy and Arabidopsis seed dormancy. Front Plant Sci, 2015. 6: p. 960.

36. Dekkers, B.J.W., et al., The Arabidopsis DELAY OF GERMINATION 1 gene affects ABSCISIC ACID INSENSITIVE 5 (ABI5) expression and genetically interacts with ABI3 during Arabidopsis seed development. Plant Journal, 2016. 85(4): p. 451-465.

37. Tabata, R., et al., Arabidopsis auxin response factor6 and 8 regulate jasmonic acid biosynthesis and floral organ development via repression of class 1 KNOX genes. Plant Cell Physiol, 2010. 51(1): p. 164-75.

38. de Jong, M., et al., TheSolanum lycopersicumauxin response factor 7 (SlARF7) regulates auxin signaling during tomato fruit set and development. The Plant Journal, 2009. 57(1): p. 160-170.

39. Koshioka, M., et al., Analysis of gibberellins in growing fruits of Lycopersicon esculentum after pollination or treatment with 4chlorophenoxyacetic acid. Journal of Pomology \& Horticultural Science, 1994. 69(1): p. 171-179.

40. Mapelli, S., et al., Relationship between set, development and activities of growth regulators in tomato fruits. Plant \& Cell Physiology, 1978. 19(7): p. 1281-1288. 
41. Sjut, V. and F. Bangerth, Induced parthenocarpy-a way of changing the levels of endogenous hormones in tomato fruits ( Lycopersicon esculentum Mill.) 1. Extractable hormones. Plant Growth Regulation, 1982. 1(4): p. $243-251$.

42. Vriezen, W.H., et al., Changes in tomato ovary transcriptome demonstrate complex hormonal regulation of fruit set. New Phytologist, 2010. 177(1): p. 60-76.

43. Chen, X., et al., Quality evaluation and chemometric discrimination of Zanthoxylum bungeanum Maxim leaves based on flavonoids profiles, bioactivity and HPLC-fingerprint in a common garden experiment. Industrial Crops and Products, 2019. 134: p. $225-233$.

44. Ke, J., et al., Application of HPLC fingerprint based on acid amide components in Chinese prickly ash (Zanthoxylum). Industrial Crops and Products, 2018. 119: p. 267-276.

\section{Figures}

$3 h$
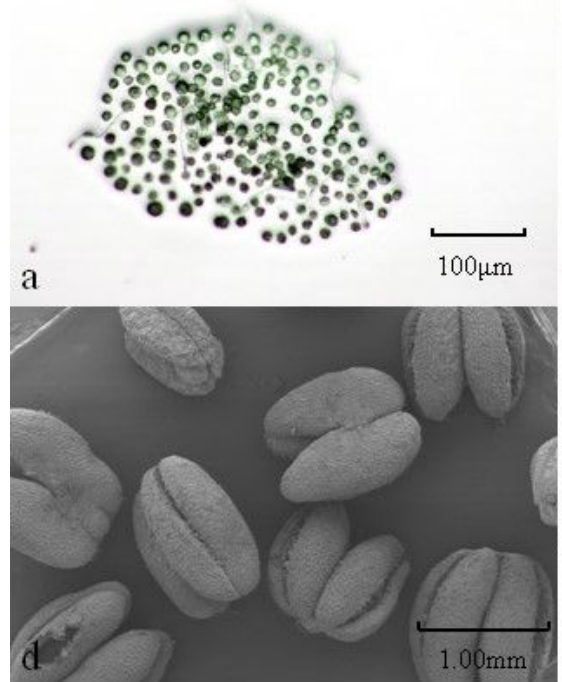

$6 \mathrm{~h}$

b
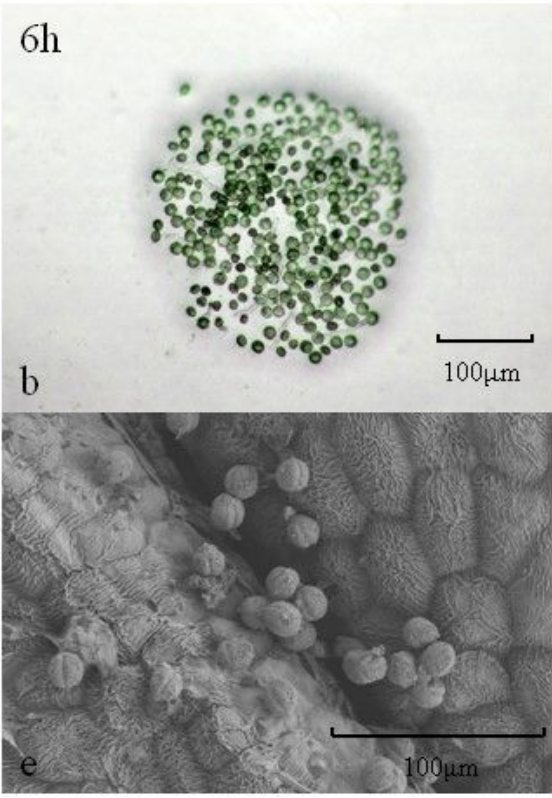

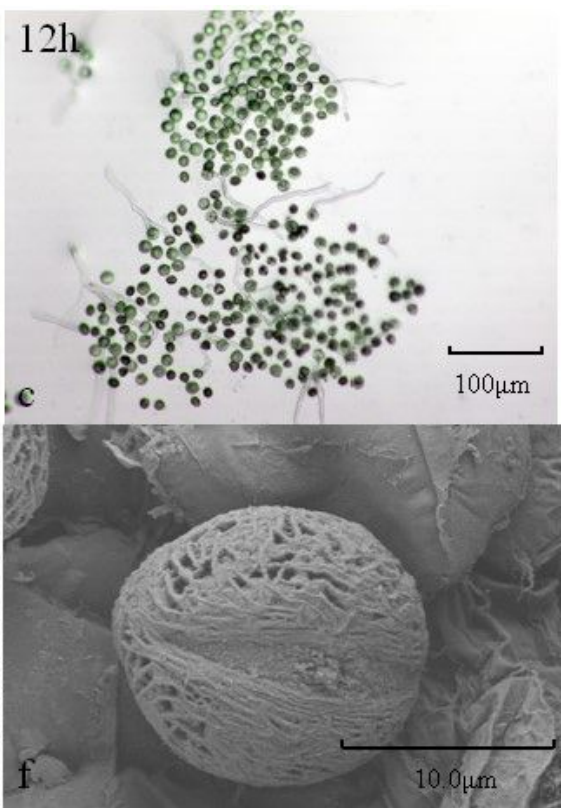

\section{Figure 1}

In vitro germination and pollen morphology of Zanthoxylum bungeanum pollen. (a) Pollen germination In vitro for 3 h, (b) Pollen germination In vitro for 6 h,

(c) Pollen germination In vitro for $12 \mathrm{~h}$, (d) anther, (e) Pollen grain, (f) Pollen grain. 


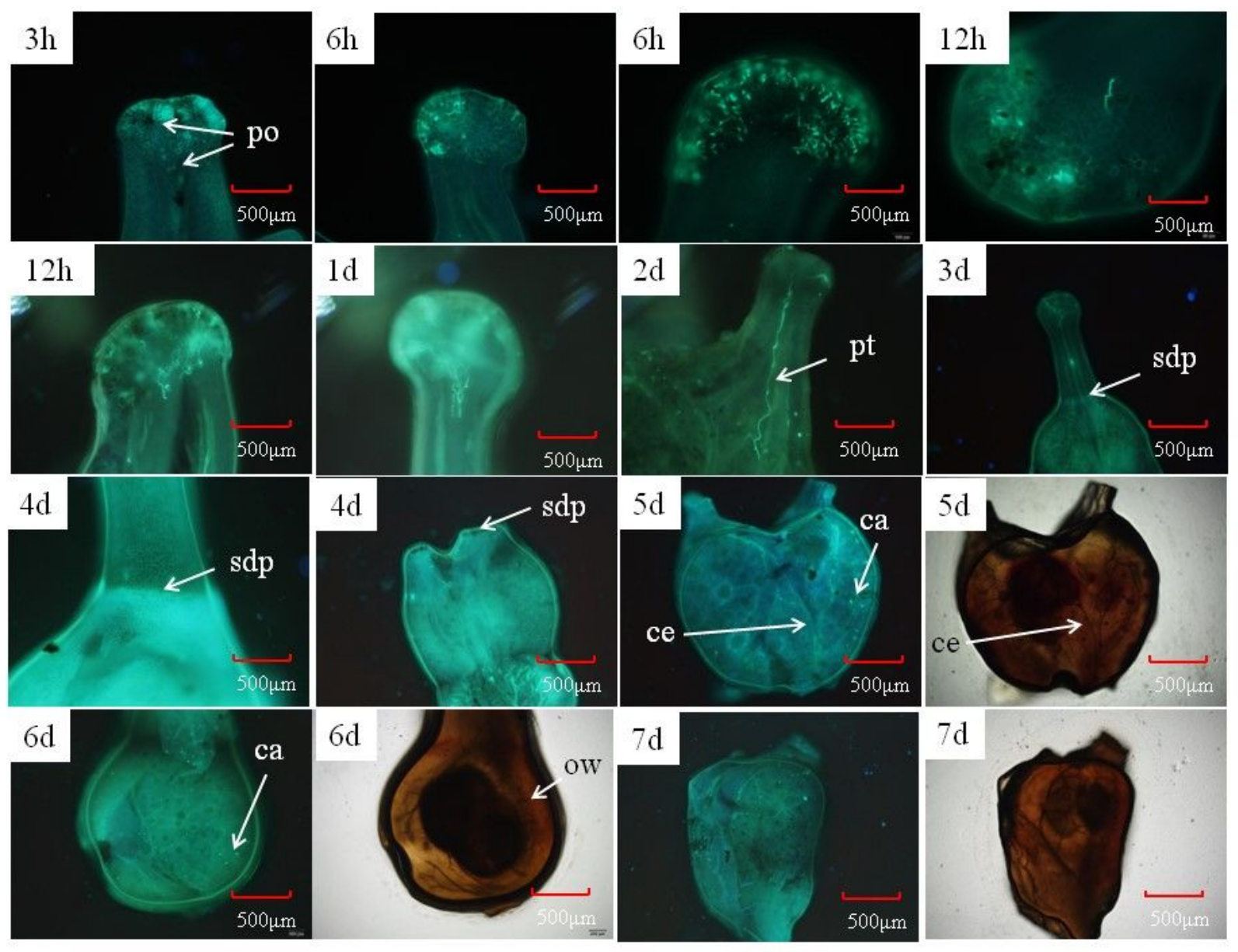

Figure 2

Germination of pollen on the stigma of Zanthoxylum bungeanum. ca: callosum, ce:cellulose, ow: ovary wall,po:pollen, pt:pollen tube, sdp: stigma drop position. 


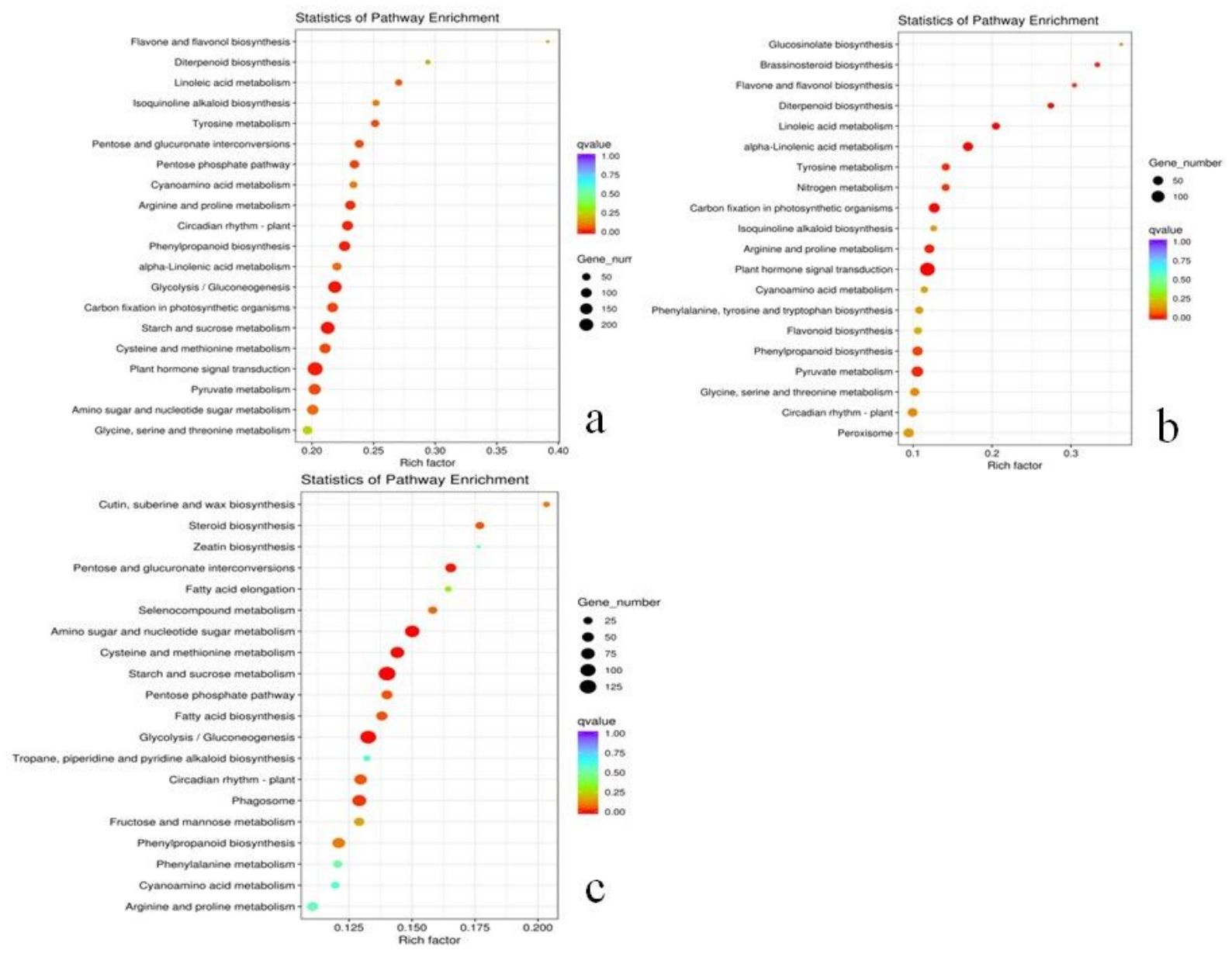

Figure 3

Path enrichment analysis. (a) Total pathway enrichment analysis. (b) Active pathway after pollination. (c) Inactive pathway after pollination.
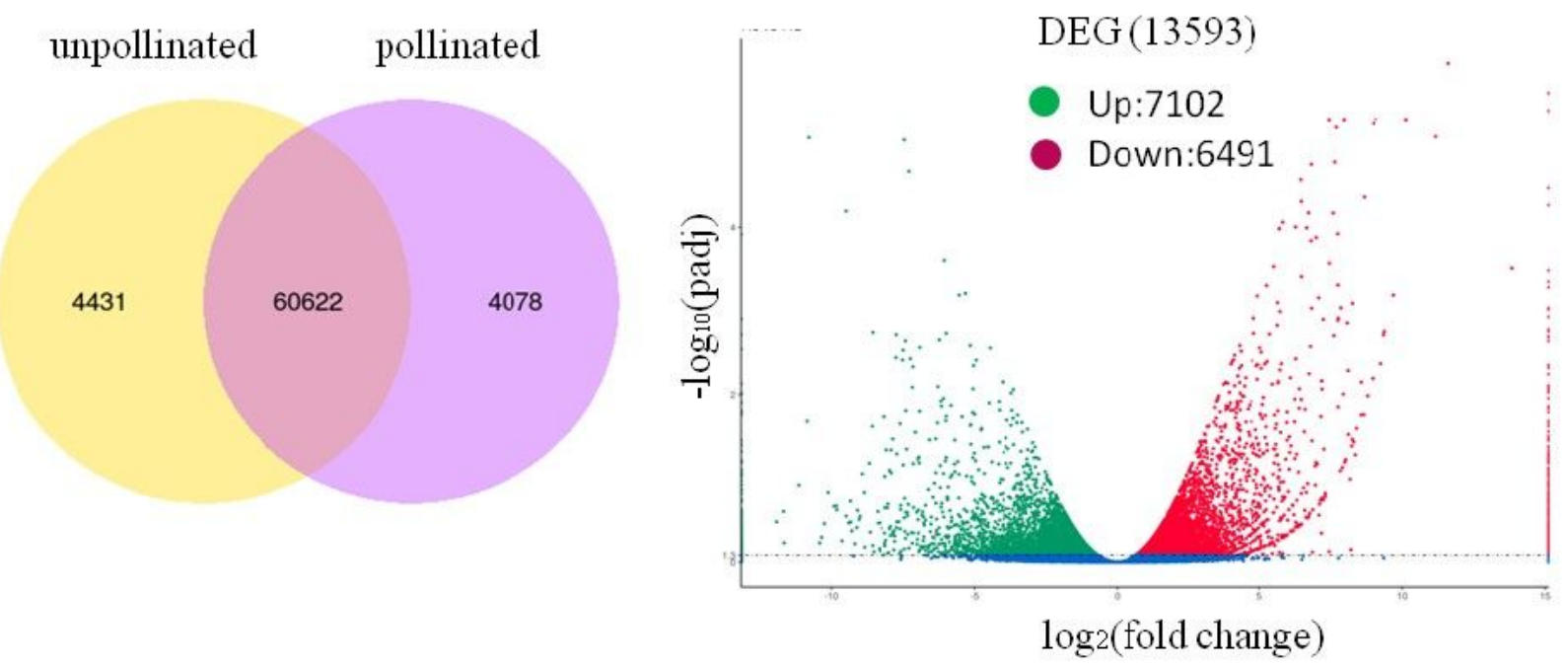

Figure 4

Differential gene Venn diagram and volcano map. 

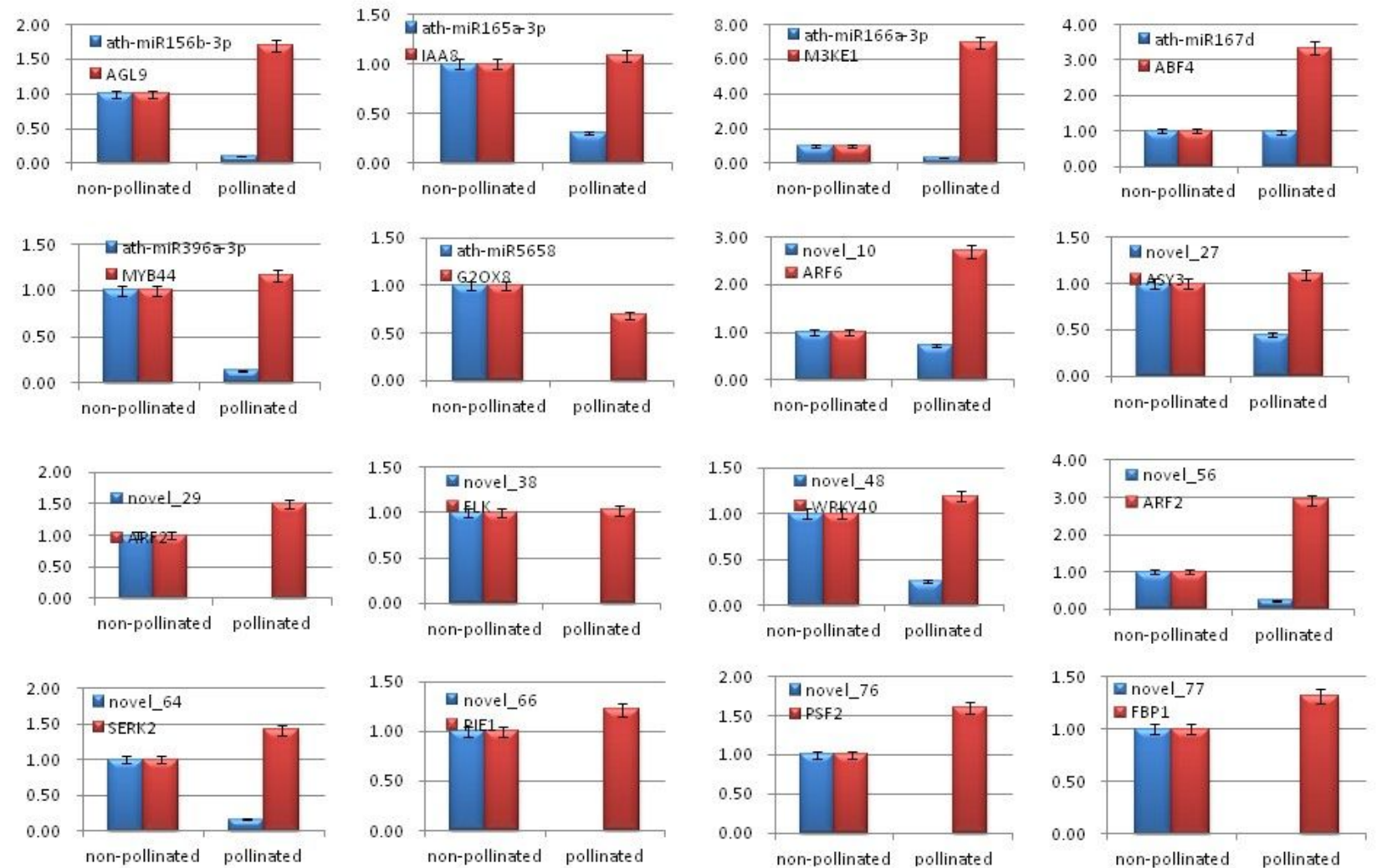

\section{Figure 5}

Relative expression levels of miRNAs and their target genes 


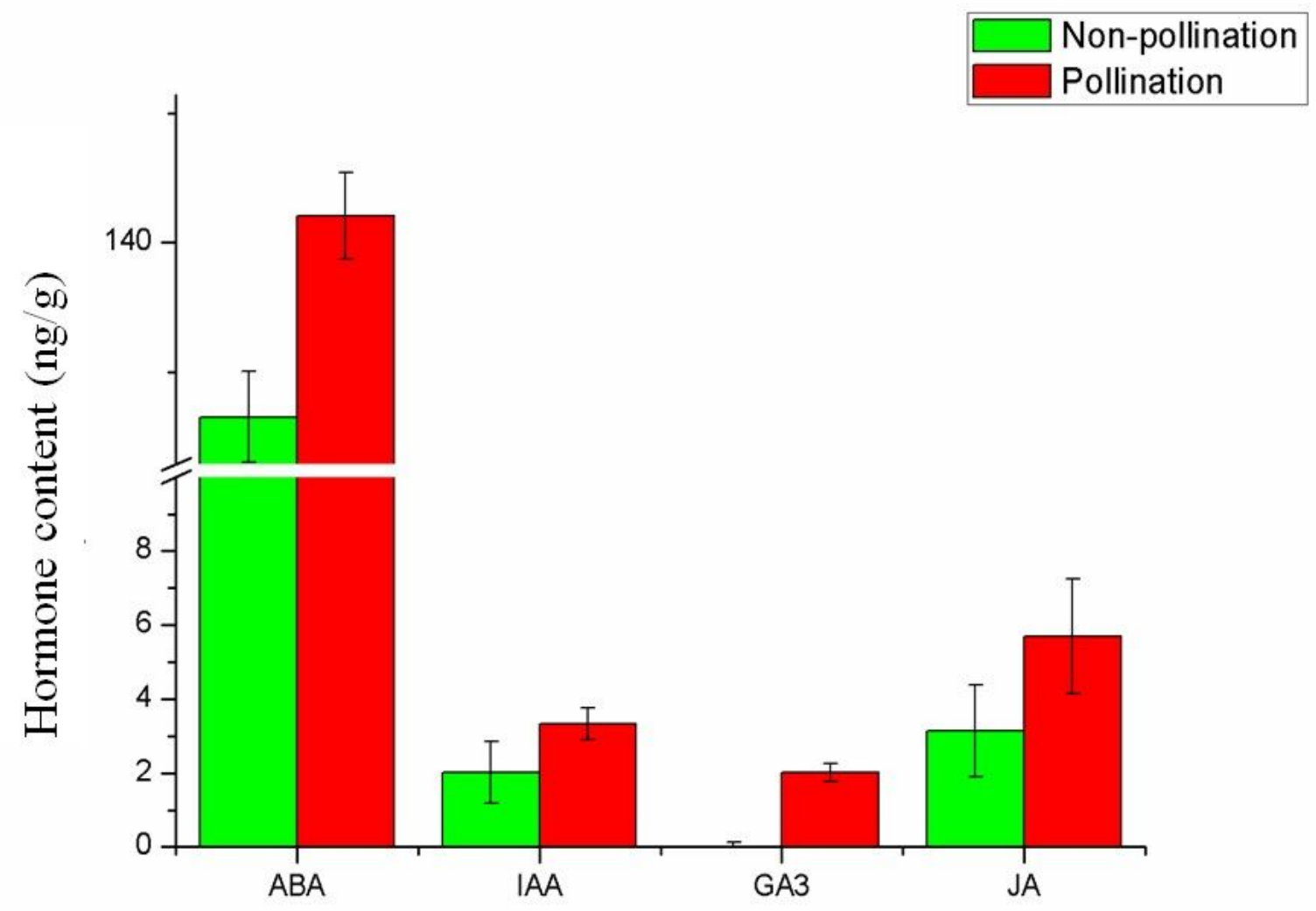

Figure 6

Hormone content of unpollinated and pollinated material of Zanthoxylum bungeanum. 


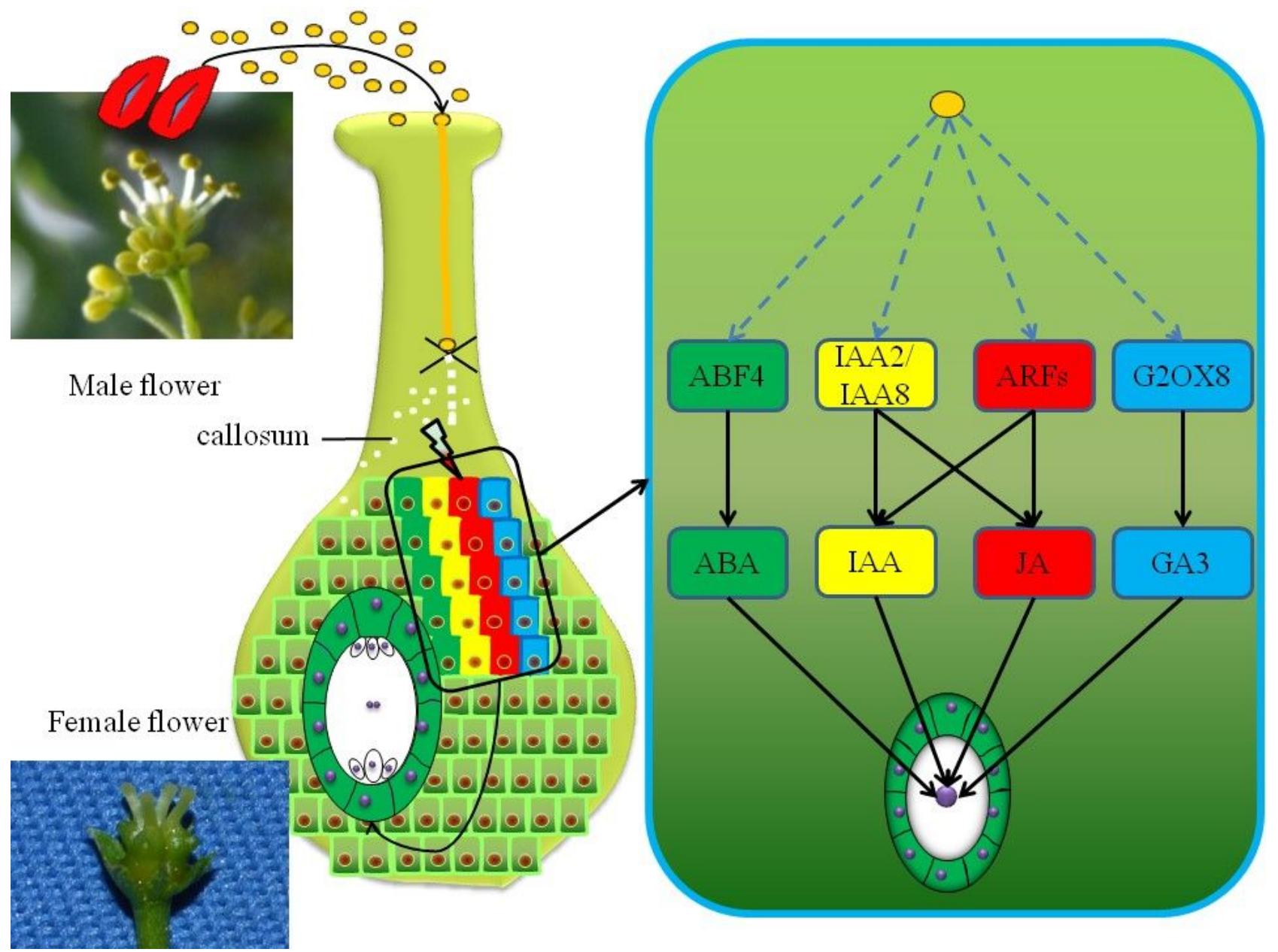

Figure 7

Hormone signal regulation model after pollination of Zanthoxylum bungeanum. 